\title{
Residents force review of biodefence lab
}

Rex Dalton, San Diego

Officials charged with distributing billions of dollars for US biodefence research are keeping a nervous eye on a small town in Montana, where residents have delayed a project to build a new pathogen-research laboratory.

A summer of discontent in Hamilton led the town's Rocky Mountain Laboratories to order a lengthy environmental assessment of its plan to build a Biosafety Level Four (BSL4) complex. BSL-4 labs are licensed to handle very contagious agents, such as ebola and smallpox. Environmental consultants were recruited last month to do the study, and the process will add 12 months to the four-year construction schedule.

The decision to build a BSL-4 lab at the Rocky Mountain centre was one of the first made by the National Institute of Allergy and Infectious Diseases (NIAID) after it was provisionally awarded $\$ 4$ billion for biodefence research in February. Of this, \$430 million was for building secure facilities. The specific pathogens to be studied have not been confirmed, but the Hamilton lab is considered a suitable venue as it already has BSL-3 facilities for studying diseases transmitted by animals. Last year's anthrax attacks focused attention on the scarcity of US facilities for biodefence research. The only large BSL-4 labs, for example, were at the Centers for Disease Control and Prevention in Atlanta, Georgia, and at a US Army base in Fort Detrick, Maryland.

Problems with consulting the 4,000 residents of Hamilton were evident early on. Lab administrators were criticized for holding the first public meeting on the evening of St Valentine's Day. At a second meeting in July, residents were told that they had just two weeks to submit comments for consideration in an environmental assessment of the lab.

"That was ludicrous," says Mary Wulff, a former policewoman who helped to found a coalition to oppose the lab's development. "Things started to snowball after that. Residents are walking around the town saying 'why don't they just put in the middle of nowhere?" The coalition complained repeatedly to the lab, citing concerns such as the inability of the region's volunteer fire and emergency teams to deal with injuries resulting from an escape of pathogens.

Faced with increasing anger from the local community, lab officials were forced to agree to a more detailed study of the environmental impact. The study could generate further legal challenges when it is released.

Officials at NIAID admit that they tried to rush the project through after last autumn's US anthrax attacks. "So many things were happening so fast, there was a national emergency under way," says Jack Killen, NIAID's assistant director for biodefence research.

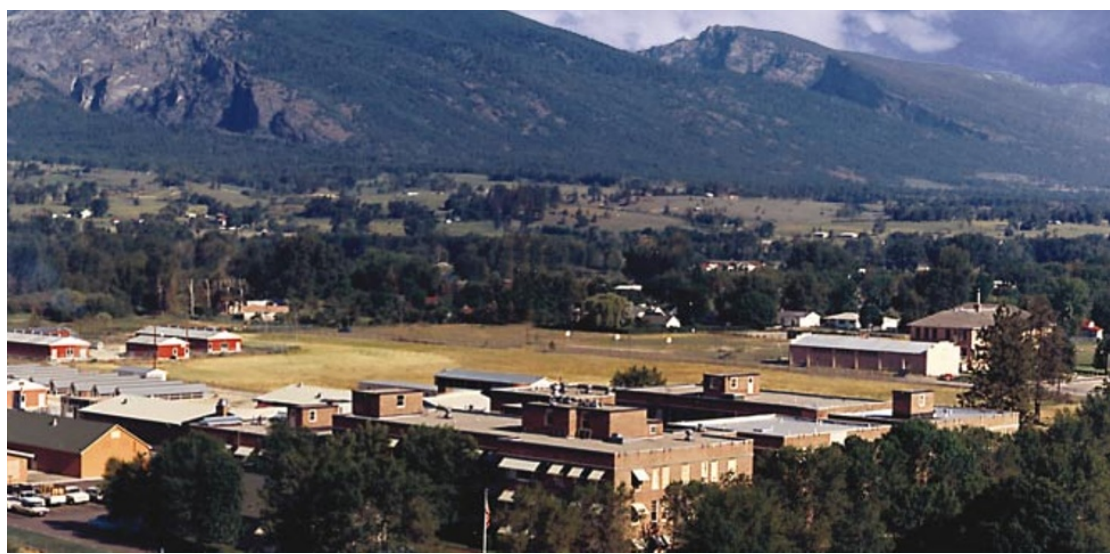

Not in my back yard: neighbours don't want a bioweapons lab added to the Rocky Mountain lab.

NIAID officials are hoping that the Rocky Mountain episode will improve their relations with the community. Staff at Rocky Mountain Laboratories have formed a committee to liaise with the community, and asked a member of Wulff's coalition to join it. But NIAID wants to build several new facilities, including two BSL-4 labs, and some bidders, such as the University of California, Davis, are situated close to large cities. Wulff says that her coalition may campaign for a more extensive environmental analysis of all US biosafety labs.
Bidders for the NIAID funding will be required to show that they have the support of the local community. NIAID officials hope that bidders can learn from more successful projects. The University of Texas Medical Branch at Galveston, for example, is building its own BSL-4 lab, for completion next year. It has gone ahead without significant resistance, partly because of an extensive education and outreach campaign by university officials. "The lesson is clear," says Killen. "You have to develop these facilities in collaboration with communities."

\section{Traditional owners 'should be paid'}

\section{Quirin Schiermeier}

Traditional knowledge can provide cheap leads for pharmaceutical companies looking for new drugs. Now a model law, unveiled at a conference last month on the South Pacific island of New Caledonia, could help to ensure that the indigenous communities involved are properly rewarded.

The law requires any company seeking to exploit traditional knowledge and culture to obtain the permission of the group that first developed it. Applications would be made through regional cultural authorities, which would be in charge of identifying and alerting the traditional owners. The owners would then have the right to reject the application or to negotiate an authorization agreement.

"It is a matter of self-respect for indigenous communities that their ownership of indigenous knowledge and culture is acknowledged in a fair way," says Kamal Puri, a lawyer at the University of Queensland in Brisbane, Australia, who co-authored the law.

The scheme is a response to cases in which drugs and cosmetic products have been derived from traditionally used plants without benefit to the indigenous community.
For example, smokebush (Conospermum spp.) has been used to develop an anti-AIDS drugs by the Australian pharmaceutical company Amrad, based in Richmond, Victoria. Amrad obtained licences from the government of Western Australia and the US National Cancer Institute, where the plant's anti-HIV activity was identified, but neither contract requires payment to the aboriginal Nyoongah people, who use smokebush for medicinal purposes. In contrast, the government of Western Australia is likely to receive royalties in excess of $\$ 100$ million per year, says Puri, if Amrad successfully develops the drug.

"The Nyoongahs have used smokebush from time immemorial. Regrettably, no one has thought of providing any remuneration to those who first discovered the medicinal properties of the drug," says Puri.

The law was discussed by patent officials, lawyers and politicians from South Pacific states on 17 September. The government of Fiji has asked Puri for assistance in passing the law. Papua New Guinea, Samoa and Tonga are considering following suit, although some small island states may lack the legal set-up to enact the law. 